\title{
Student Engagement in Hybrid Task-Based Language Teaching in EFL Writing Class
}

\author{
Tusino $^{1}$, Abdurrachman Faridi ${ }^{2}$, Mursid Saleh $^{3}$, Sri Wuli Fitriati ${ }^{4}$ \\ \{tusino@umpwr.ac.id ${ }^{1}$, pakdur@yahoo.co.id ${ }^{2}$, mursids@ @otmail.com ${ }^{3}$, \\ sriwuli.fitriati@mail.unnes.ac.id $\left.{ }^{4}\right\}$
}

Universitas Negeri Semarang ${ }^{1234}$, Jl. Kelud Utara III, Semarang 50237 Indonesia ${ }^{1234}$

\begin{abstract}
College teachers are seeking innovative learning environment and teaching technologies to encourage better performance for their students. Hybrid task-based language teaching is a combination between traditional learning and online learning in terms of giving tasks which consists of pre-task, during-task, and post-task cycles. This study aims at describing how college students engage in hybrid task-based language teaching and revealing their perceptions of its implementation in EFL writing class. Twenty six undergraduate students majoring English program are employed as research participants. The instruments used were open-response questionnaires and in-depth interviews in the writing course. Data were taken from student responses of questionnaires and interviews. The data were processed through descriptive qualitative analysis, namely categorizing student writing of open-response questionnaires, transcribing interviews results, analyzing the encoded data, and drawing conclusions. The results of the study show that students are more engaged in hybrid classes assisted with a Google Classroom tool. Hybrid learning increases students' task completions and their learning motivation. However, task complexity and submission deadline hinder hybrid learning processes. Student-student and instructor-student communication through both face-to-face and online learning are correlated with higher student engagement.
\end{abstract}

Keywords: student engagement, hybrid task-based language teaching, EFL writing

\section{Introduction}

Writing is seen as among the most crucial skills by foreign language students due to its productive role in communication. EFL students see writing skill as a complex process. Students in university levels get many problems in writing English covering linguistic, cognitive, and affective problems [1], [2], [3]. Consequently, college teachers need to find effective learning models to overcome writing problems faced by their students.

Task-based language teaching (TBLT) is an instructional pedagogy in which communication tasks are fundamental to language learning [4], [5], [6]. In English learning, TBLT has attracted a great attention from many researchers [7], [8], in particular to writing classes [9], [10], [11], [12]. It shows that TBLT gives effects on enhancing students' language skills and components.

The massive usage of learning technology especially for internet devices in educational contexts has afforded universities to find out another means to expand the delivery of curricula to students. TBLT integrated with technology has attracted many scholars to investigate in 
language learning. They prove that technology-mediated TBLT can help students improve their language proficiency [13], [14], [15], [16], [17].

Hybrid learning, also known as blended learning, is a new approach in delivering programs to learners. In a hybrid approach, online components are integrated with face-to-face learning to suit the changing needs of the students who assume or prefer the presence of online learning as part of their engagement with their studies [18]. Hybrid TBLT is a learning model where the college teacher integrates technology in terms of giving series of tasks assisted with a Google Classroom tool. In this study, hybrid TBLT is a combination between traditional learning and online learning to provide pedagogical tasks which consists of pre-task, during task, and post-task cycles.

Engagement reflects the process and product experienced on a continuum and results from the synergistic interaction between motivation and active learning [19]. Some scholars describe engagement differently as having multiple subtypes. [20] include academic (e.g. time on task, credit hours towards graduation, homework completion), behavioral (e.g. attendance, classroom participation, extracurricular participation, suspensions), cognitive (e.g. selfregulation, relevance of school to future aspirations, value of learning, strategizing, autonomy), and psychological subtypes (e.g. belonging, relationship with teachers and peers). Since student engagement is documented as a prerequisite for effective learning [21], this concept needs serious concerns by college teachers. Student engagement, thus, is an integral part of hybrid learning environments.

Engagement in hybrid learning environment has been studied by several researchers [22], [23], [24]. The results of the study show that students prefer online activities but acknowledge that in-class activities help them learn course work. Teachers' social engagement also influences students' ability to study and use technology. It proves that students have positive engagement in hybrid learning environment for their learning process.

From the previous explanations, it is clear that most hybrid learning studies are conducted in ESL classrooms. Only a few are conducted in EFL settings, and accounts of integrating TBLT with technology using Google Classroom in Indonesia are still scarce. It is, therefore, novel and significant to explore the application of hybrid TBLT in EFL writing contexts for Indonesian college students. This study aims at describing student engagement in hybrid TBLT and finding out the perceived benefits and challenges of applying it in EFL writing class. The results of the study can provide educators the necessary requirements needed to engage students towards a successful delivery of hybrid TBLT environment. Educational leaders could use the information to establish policies and guidelines in the delivery of hybrid TBLT. The hybrid environment also provides students with the opportunity to socially engage with their peers and college teachers using both face-to-face and online classroom discussions.

\section{Methods}

This study employed a qualitative case study with undergraduate students at a local private university in Central Java, Indonesia. The students were EFL learners at the second year enrolling a writing course in spring 2019. Twenty six undergraduate students majoring English program were selected as research participants. The class consisted of twenty females and six males at the age of 19-21. All students had mobile phones and notebooks used as learning media for writing activities with the use of Google Classroom. 
Data were collected and triangulated through multiple sources involving open-response questionnaires and in-depth interviews. Open-response questionnaires with entire class students were used to explore student engagement; meanwhile, interviews were employed to reveal students' perceptions towards practices of hybrid TBLT in writing processes. Questionnaire checklists consisted of fifteen items, while interview guides comprised six questions. The questionnaire items employed [20] idea that student engagement has four multiple subtypes: academic, behavioral, cognitive, and psychological. Interview guides led students to explore benefits and challenges of applying hybrid TBLT in the writing course.

In the data collection, open-response questionnaires were executed after students practiced writing using a Google Classroom tool. Afterwards, in-depth interviews with six students for fifteen minutes for each participant were conducted after learning class. All student responses of questionnaire items were coded qualitatively using a thematic analysis. Also, the interviews were audio-recorded to display the data. The data were processed through descriptive qualitative analysis, namely coding students' written and spoken responses, analyzing the encoded data, and drawing conclusions.

\section{Results and Discussion}

Results are presented according to research purposes of the study. The first objective is to describe student engagement in hybrid TBLT in EFL writing class shown in tables 1 and 2.

Table 1. Summary of statements per indicator

\begin{tabular}{|c|c|c|c|}
\hline \multirow[b]{2}{*}{$\begin{array}{l}\text { Engagement } \\
\text { subtypes }\end{array}$} & \multirow[b]{2}{*}{ Indicator } & \multicolumn{2}{|c|}{ Frequency } \\
\hline & & $\begin{array}{l}\text { Positive } \\
\text { statement }\end{array}$ & $\begin{array}{l}\text { Negative } \\
\text { statement }\end{array}$ \\
\hline \multirow[t]{4}{*}{ Academic } & Time on task & 23 & 3 \\
\hline & Credit hours towards graduation & 11 & 15 \\
\hline & Homework completion & 18 & 8 \\
\hline & Academic engagement (\%) & $52(67 \%)$ & $26(33 \%)$ \\
\hline \multirow[t]{5}{*}{ Behavioral } & Attendance & 23 & 3 \\
\hline & Classroom participation & 25 & 1 \\
\hline & Extracurricular participation & 17 & 9 \\
\hline & Suspensions & 25 & 1 \\
\hline & Behavioral engagement (\%) & $90(87 \%)$ & $14(13 \%)$ \\
\hline \multirow[t]{6}{*}{ Cognitive } & Self-regulation & 19 & 7 \\
\hline & $\begin{array}{l}\text { Relevance of school to future } \\
\text { aspirations }\end{array}$ & 20 & 6 \\
\hline & Value of learning & 7 & 19 \\
\hline & Strategizing & 8 & 18 \\
\hline & Autonomy & 22 & 4 \\
\hline & Cognitive engagement $(\%)$ & $76(58 \%)$ & $54(42 \%)$ \\
\hline \multirow{5}{*}{ Psychological } & Belonging & 13 & 13 \\
\hline & Relationship with teachers & 18 & 8 \\
\hline & Relationship with peers & 23 & 3 \\
\hline & Psychological engagement (\%) & $54(71 \%)$ & $29(\%)$ \\
\hline & Total $(\%)$ & $272(69 \%)$ & $118(31 \%)$ \\
\hline
\end{tabular}


Table 2. Examples of statement per indicator

\begin{tabular}{|c|c|c|c|}
\hline \multirow{2}{*}{$\begin{array}{l}\text { Engagement } \\
\text { subtypes }\end{array}$} & \multirow{2}{*}{ Indicator } & \multicolumn{2}{|c|}{ Examples of statement } \\
\hline & & Positive statement & Negative statement \\
\hline \multirow[t]{3}{*}{ Academic } & Time on task & $\begin{array}{l}\text { "I always stay on } \\
\text { writing tasks given by } \\
\text { the teacher." }\end{array}$ & $\begin{array}{l}\text { "Use of technology disturbs } \\
\text { me to do the tasks." }\end{array}$ \\
\hline & $\begin{array}{l}\text { Credit hours } \\
\text { towards graduation }\end{array}$ & $\begin{array}{l}\text { "I can perform well } \\
\text { during task completion } \\
\text { as instructed." }\end{array}$ & $\begin{array}{l}\text { "This learning model } \\
\text { burdens me to complete the } \\
\text { tasks as a whole”. }\end{array}$ \\
\hline & $\begin{array}{l}\text { Homework } \\
\text { completion }\end{array}$ & $\begin{array}{l}\text { "I can accomplish the } \\
\text { tasks easily from home." }\end{array}$ & $\begin{array}{l}\text { "I get difficulty to complete } \\
\text { the tasks on time due to } \\
\text { error online submission." }\end{array}$ \\
\hline \multirow[t]{4}{*}{ Behavioral } & Attendance & $\begin{array}{l}\text { "I like to join a writing } \\
\text { class for online and } \\
\text { face-to-face classroom } \\
\text { discussions." }\end{array}$ & $\begin{array}{l}\text { "Sometimes I feel bored } \\
\text { about writing class." }\end{array}$ \\
\hline & $\begin{array}{l}\text { Classroom } \\
\text { participation }\end{array}$ & $\begin{array}{l}\text { "I am confident to make } \\
\text { online questions related } \\
\text { to the given tasks." }\end{array}$ & $\begin{array}{l}\text { "I feel ashamed of making } \\
\text { comments due to } \\
\text { psychological effects." }\end{array}$ \\
\hline & $\begin{array}{l}\text { Extracurricular } \\
\text { participation }\end{array}$ & $\begin{array}{l}\text { "Online tasks out of } \\
\text { class improve my } \\
\text { involvement during } \\
\text { writing process." }\end{array}$ & $\begin{array}{l}\text { "I don't like to have writing } \\
\text { tasks due to burdening my } \\
\text { school life." }\end{array}$ \\
\hline & Suspensions & $\begin{array}{l}\text { "I give comments on } \\
\text { online discussions." }\end{array}$ & $\begin{array}{l}\text { "I feel unmotivated to write } \\
\text { without teacher monitors." }\end{array}$ \\
\hline \multirow[t]{5}{*}{ Cognitive } & Self-regulation & $\begin{array}{l}\text { "I can accomplish the } \\
\text { tasks as instructed." }\end{array}$ & $\begin{array}{l}\text { "Constructing writing ideas } \\
\text { is complicated." }\end{array}$ \\
\hline & $\begin{array}{l}\text { Relevance of school } \\
\text { to future aspirations }\end{array}$ & $\begin{array}{l}\text { "Writing processes are } \\
\text { beneficial for developing } \\
\text { my critical thinking." }\end{array}$ & $\begin{array}{l}\text { "Some issues for writing } \\
\text { tasks are out of date." }\end{array}$ \\
\hline & Value of learning & $\begin{array}{l}\text { "I feel motivated when } \\
\text { getting controversial } \\
\text { issues to write." }\end{array}$ & $\begin{array}{l}\text { "I get bored when getting } \\
\text { common topics to write." }\end{array}$ \\
\hline & Strategizing & $\begin{array}{l}\text { "I use mind-mapping } \\
\text { techniques and } \\
\text { synonyms for idea }\end{array}$ & $\begin{array}{l}\text { "I copy ideas from internet } \\
\text { when finding difficulty in } \\
\text { writing." }\end{array}$ \\
\hline & Autonomy & $\begin{array}{l}\text { constructions in writing. } \\
\text { "I can write by myself } \\
\text { using references from } \\
\text { books and journals." }\end{array}$ & $\begin{array}{l}\text { "I ask my friend easily } \\
\text { when I get stuck in } \\
\text { writing." }\end{array}$ \\
\hline \multirow[t]{3}{*}{ Psychological } & Belonging & $\begin{array}{l}\text { "I focus on learning in } \\
\text { class for task } \\
\text { completions. }\end{array}$ & $\begin{array}{l}\text { "Google Classroom tool } \\
\text { rather disturbs my writing } \\
\text { process due to ease of } \\
\text { online plagiarism."” }\end{array}$ \\
\hline & $\begin{array}{l}\text { Relationship with } \\
\text { teachers }\end{array}$ & $\begin{array}{l}\text { "I always pay attention } \\
\text { to the teacher } \\
\text { explanations and } \\
\text { corrections." }\end{array}$ & $\begin{array}{l}\text { "Teacher's explanations } \\
\text { are rather confusing." }\end{array}$ \\
\hline & $\begin{array}{l}\text { Relationship with } \\
\text { peers }\end{array}$ & $\begin{array}{l}\text { "I talk with my friends } \\
\text { on tasks." }\end{array}$ & $\begin{array}{l}\text { "I chat online with my } \\
\text { friends out of tasks." }\end{array}$ \\
\hline
\end{tabular}


Discussion is presented using the subtypes of student engagement [20] and the categories of students' perceptions towards implementation of hybrid TBLT in EFL writing. Table $\mathbf{1}$ and 2 show student engagement in general seen from a total percentage of positive and negative statements. There are $272(69 \%)$ positive statements compared to $118(31 \%)$ negative ones figuring out that students are more engaged [25] in learning writing with the use of hybrid TBLT. Students are engaged in the phases of writing tasks using both face-to-face and online discussions.

Academic engagement is highlighted by the participants in the discussion of all three questions related to time on task, credit hours towards graduation, and homework completion. Most participants (67\%) indicate that they can have good academic engagement like always focusing on tasks [15], but some of them (33\%) are disturbed by the technology when learning writing using hybrid TBLT. However, most students are not well-performed for task completions. This reveals that hybrid TBLT cannot enhance students' writing performance, but it eases the task completions due to technology assistance. This technology makes students no need to meet the teacher in person, but they can submit their tasks anywhere and anytime.

Behavioral engagement is highlighted by participants' comments on attendance, classroom participation, and suspensions. Most participants (87\%) show positive behavioral engagement when they are asked to practice writing using hybrid TBLT. They participate actively during face-to-face and online classroom discussions [26]. The use of private comments used as teacher feedbacks on Google Classroom motivates them to engage in writing phases. However, they feel unmotivated to practice writing without teacher's monitors in class. Students believe that they need face-to-face lectures for evaluating their progress in writing. The combination of traditional and online learning models is more recommended rather than using a single mode of learning.

Cognitive engagement is described by the participants when they join writing processes related to self-regulation, relevance of school to future aspirations, value of learning, strategizing, and autonomy. Many participants (54\%) illustrate that they have positive cognitive engagement in self-regulation. Most comment that they can do the tasks as instructed. However, students feel bored when they are assigned to write with ordinary topics. They also copy others' writings from internet sources as they get stuck to build ideas. This case becomes foremost issues for using hybrid learning.

Participants comment on psychological engagement related to three indicators, namely belonging and relationship with teachers and peers. Most participants $(71 \%)$ indicate that they are good at psychological engagement. They have positive relationship with their teacher and peers. Students like to conduct online discussions with their teacher and peer related to the given tasks. However, they sometimes like to talk with their peers out of tasks in particular to the process of idea buildings. Hybrid TBLT psychologically disturbs students' writing process due to ease of online plagiarism.

The second objective of the study, furthermore, is to find out the perceived benefits and challenges of applying it in EFL writing class as shown in tables 3 and $\mathbf{4}$. 
Table 3. Summary of statement per category

\begin{tabular}{lll}
\hline Perceptions & Coding category & Frequency $(\%)$ \\
\hline Benefits & Learning motivation & $5(21 \%)$ \\
& Flexible submission of tasks & $5(21 \%)$ \\
& Development of writing technique & $1(4 \%)$ \\
& Delivery of materials & $1(4 \%)$ \\
& Direct teacher's feedback & $2(8 \%)$ \\
Challenges & Deadline of task submission & $5(21 \%)$ \\
& Complex tasks & $4(17 \%)$ \\
& Financial challenges & $1(4 \%)$ \\
& Total (\%) & $24(100 \%)$ \\
\hline
\end{tabular}

Table 4. Examples of statement per category

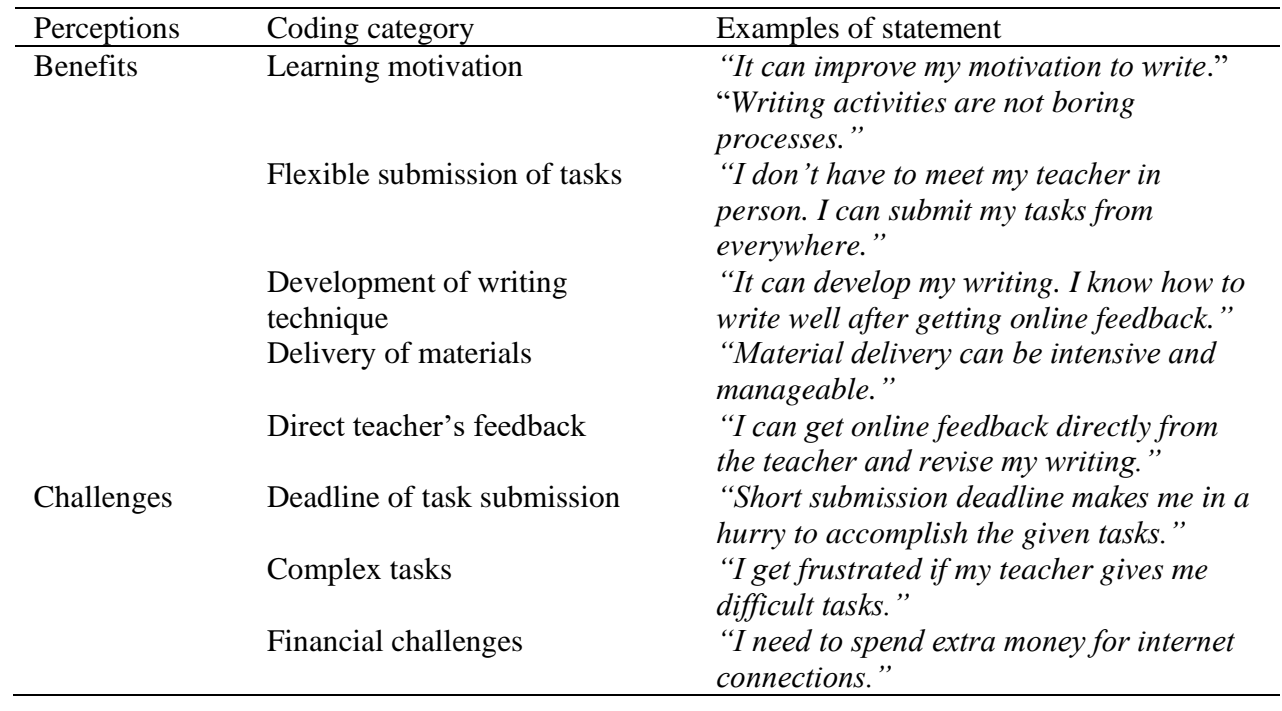

As seen from tables 3 and 4, benefits of hybrid TBLT are disclosed by participants' feedbacks as being interviewed in regard to implementation of the learning model in the writing class. Participants also refer to learning motivation and flexible task submissions [27] as the most important benefits of using hybrid TBLT. Students are excited to learn since the technology causes paperless learning for task submissions. Other advantages are development of writing techniques, efficient delivery of materials, and direct teacher's feedbacks. Virtual writing classes provide material delivery in real time for students. Furthermore, face-to-face lectures in group-work activities [28] are needed to explain complex materials and direct feedbacks from the teacher.

Participants also perceive challenges to conduct hybrid TBLT in the writing processes. Most students complain about deadline of task submission, levels of task complexity, and financial challenges [22]. As they are asked to write difficult topics, they still need much time for writing over deadline given by the teacher. Submission due and task complexity levels cause participants in a hurry situation for writing task completions. The students also have additional financial expenditures for having internet connections for joining the writing course. 


\section{Conclusion}

The findings of this study highlight that activating learning environment in pairs or small group discussions during both face-to-face and online activities is able to promote student engagement. Also, good communication between student-student and student-instructor has contribution with higher student engagement. EFL college teacher and students hold opinions that hybrid TBLT is effective and plays a positive role to motivate students and to increase their task completions. The students show positive engagement towards TBLT assisted with Google Classroom, as majority of students like to work collaboratively with their peers discussing their writings. However, levels of task complexity and submission due date cause hybrid learning activity incapable of running smoothly.

Hybrid learning leads student-writers critical to their own writings, eases task completions, and develops collaborative learning. Due to task complexity levels, college teachers have to conduct training of peer online discussions so that students are able to comments other works precisely. In addition, challenging tasks and controversial issues can be used by college teachers to develop students' motivations in writing processes. Students have to motivate themselves to take active participation during traditional and online discussions in order to enhance their writing engagement. A longitudinal study, furthermore, needs to be conducted for further investigations in particular to cognitive and psychological engagement with larger scales.

Acknowledgment. The authors would like to acknowledge financial support for this research from Indonesia Endowment Fund for Education with a contract number: S1984/LPDP.3/2017. 


\section{References}

[1] Al Mubarak, A. A.: An investigation of academic writing problems level faced by undergraduate students at Al Imam Al Mahdi university - Sudan. English Review: Journal of English Education, Vo. 5 No. 2, pp. 175-188 (2017)

[2] Wellington, J.: More than a matter of cognition: An exploration of affective writing problems of post-graduate students and their possible solutions. Teaching in Higher Education, Vo. 15 No. 2, pp. $135-150$ (2010)

[3] Zabihi, R. The role of of cognitive and affective factors in measures of L2 writing. Written Communication, pp. 1-26 (2017)

[4]Ellis, R. Position paper: Moving task-based language teaching forward. Lang. Teach. Vol. 50 No. 4, pp. 507-526 (2017)

[5]Long, M. H.: In defense of tasks and TBLT: Nonissues and real issues. Annual Review of Applied Linguistics, Vo. 36, pp. 5-33 (2016)

[6]Skehan, P.: Tasks versus conditions: Two perspectives on task research and their implications for language pedagogy. Annual Review of Applied Linguistics, Vol. 36, pp. 34-49 (2016)

[7] Adiantika, H. N. \& Purnomo, H.: The implementation of task-based instruction in EFL teaching speaking skill. Indonesian EFL Journal, Vol. 4 No. 2, pp. 12-22 (2018)

[8] Calvert, M., \& Sheen, Y.: Task-based language learning and teaching: An action-research study. Language Teaching Research, Vol. 8, pp. 1-19 (2014)

[9] Manikowati, M., \& Bharati, D. A. L.: The effectiveness of multimedia in teaching writing to the students with different learning styles. English Education Journal, Vo. 7 No. 2, pp. 85-91 (2017)

[10] Rahimi, M., \& Zhang, L. J.: Effects of task complexity and planning conditions on L2 argumentative writing production. Discourse Processes, Vo. 8, pp. 1-17 (2017)

[11] Sari, N. N. R., Tantra, D. K., \& Santosa, M. H.: Task-based language teaching and text types in teaching writing using communicative approach. SHS Web of Conferences, Vo. 42, pp. 1-6. (2018)

[12] Widayanti, M. J. A.: Enhancing students' writing skill through task-based approach. Language Circle: Journal of Language Literature, Vo. 8 No. 1, pp. $27-39$ (2011)

[13] Adams, R., Amani, S., Newton, J. \& Alwi, N.: Planning and production in computer-mediated communication (CMC) writing. In Brynes, H., \& Manchón, R. M. (Eds.), Language Publishing Co. (2014)

[14] Baralt, M. \& Gomez, J. M.: Task-based language teaching online: A guide for teachers. Language Learning and Technology, Vol 21 No. 3, pp. 28-43 (2017)

[15] Lai, C., Zhao, Y., \& Wang, J.: Task-based language teaching in online ab initio foreign language classrooms. The Modern Language Journal, Vo. 11, pp. 81-103 (2011)

[16] Oskoz, A. \& Elola, I. Promoting foreign language collaborative writing through the use of web 2.0 tools and tasks. In Gonzalez-Lloret, M., \& Ortega, L. (Eds.), Technology-mediated TBL (pp. 115-148). Amsterdam: John Benjamins Publishing Co. (2014)

[17] Park, M.: Implementing computer-assisted task-based language teaching in the Korean secondary EFL context. In Shehadeh, A., \& Coombe, C. A. (Eds.). Task-Based Language Teaching in Foreign Language Contexts. (pp. 215-231). Amsterdam: John Benjamins Publishing Co. (2012)

[18] Jefferies, A., \& Hyde, R.: Building the future student's blended learning experience from current research findings. Electronic Journal of e-Learning, Vo. 8 No. 2, pp. 133-140 (2010)

[19] Barkley, E. F. Student engagement techniques. A handbook for college faculty. San Francisco: Jossey-Bass (2010)

[20] Appleton, J. J., Christenson, S. L., Kim, D., \& Reschly, A. L.: Measuring cognitive and psychological engagement: Validation of the student engagement instrument. Journal of School Psychology, Vo. 44, pp. 427-445 (2006)

[21] Baker, W., \& Pittaway, S.: The application of a student engagement framework to the teaching of music education in an e-learning context in one Australian university. Proceedings of the 4th Paris International Conference on Education, Economy and Society, Paris, France (pp. 27-38) (2012) 
[22] Delialioğlu, Ö.: Student engagement in blended learning environments with lecture-based and problem-based instructional approaches. Educational Technology \& Society, Vol. 15 No. 3, 310-322 (2012)

[23] Eliveria, A., Serami, L., Famorca, L. P., Dela Cruz, J.S.: Investigating students' engagement in a hybrid learning environment. Proceedings of the International Conference on Information Technology and Digital Applications. IOP Conf. Series: Materials Science and Engineering 482 (2019)

[24] Johnson, E., Morwane, R., Dada, S., Pretorius, G., \& Lotriet, M.: Adult learners' perspectives on their engagement in a hybrid learning postgraduate programme. The Journal of Continuing Higher Education, Vo. 66 No. 2, pp. 88-105 (2018)

[25] Lin, Q.: Student views of hybrid learning: A one-year exploratory study. Journal of Computing in Teacher Education, Vo. 25 No. 2, pp. 57-66 (2008)

[26] Rashid, S., Watson, K., \& Cunningham, U.: Task-based language teaching with smartphones: A case study in Pakistan. Teachers and Curriculum, Vo. 17, pp. 2, 33-40 (2017)

[27] Vaughan, N.: Student engagement and blended learning: Making the assessment connection. Education Sciences, Vo. 4, pp. 247-264 (2014)

[28] Hao, D. T. T.: Task-based language teaching: An insight into teacher practice. International Journal of Education, Culture and Society. Vo. 2 No. 4, pp. 126-131 (2017) 